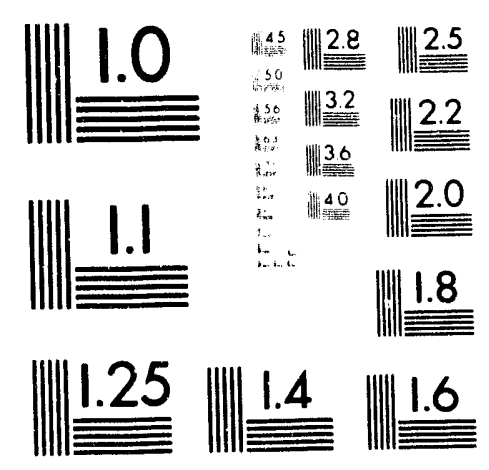



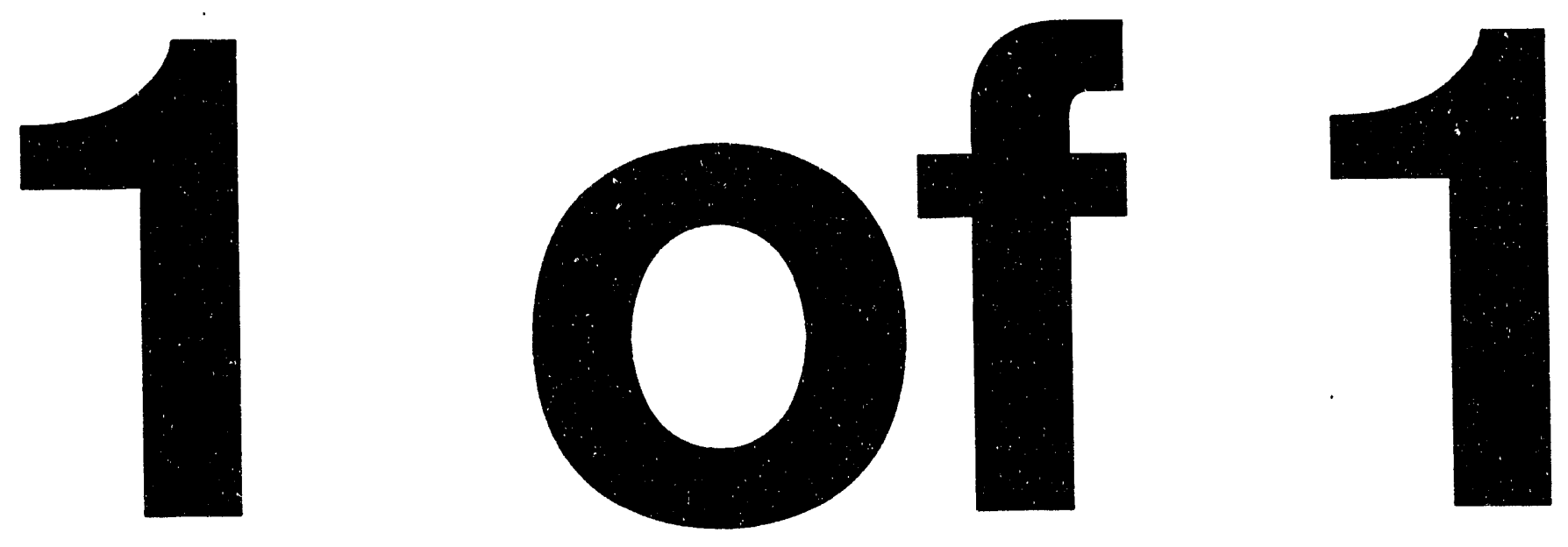

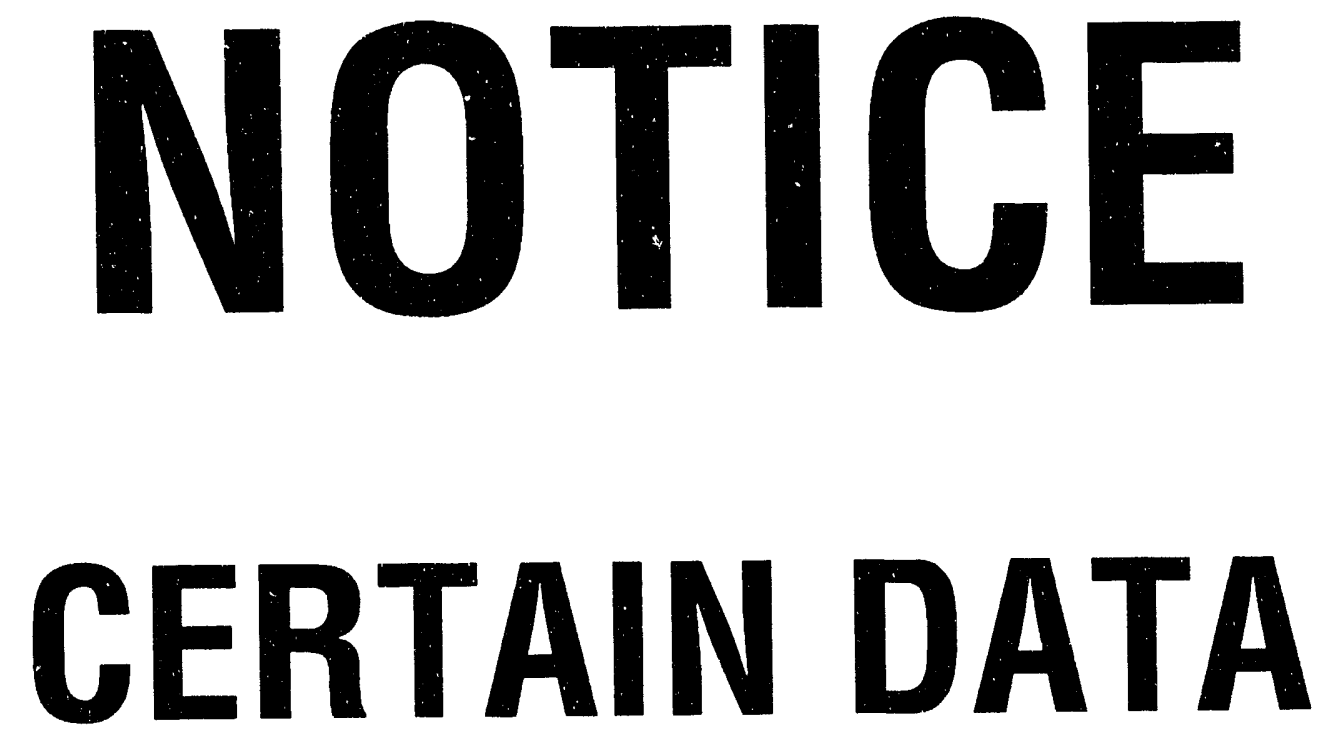

CONTAINED IN THIS
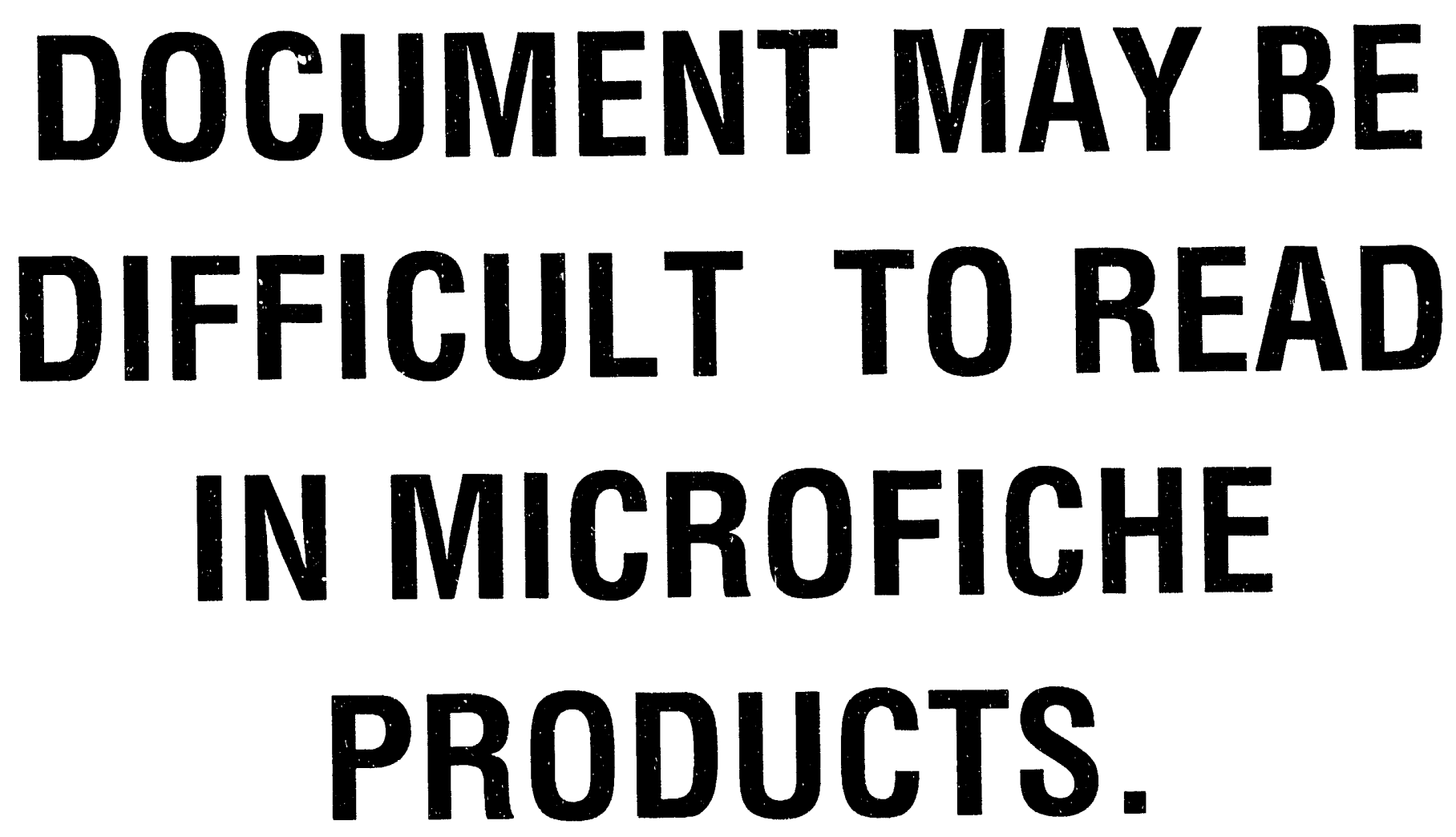

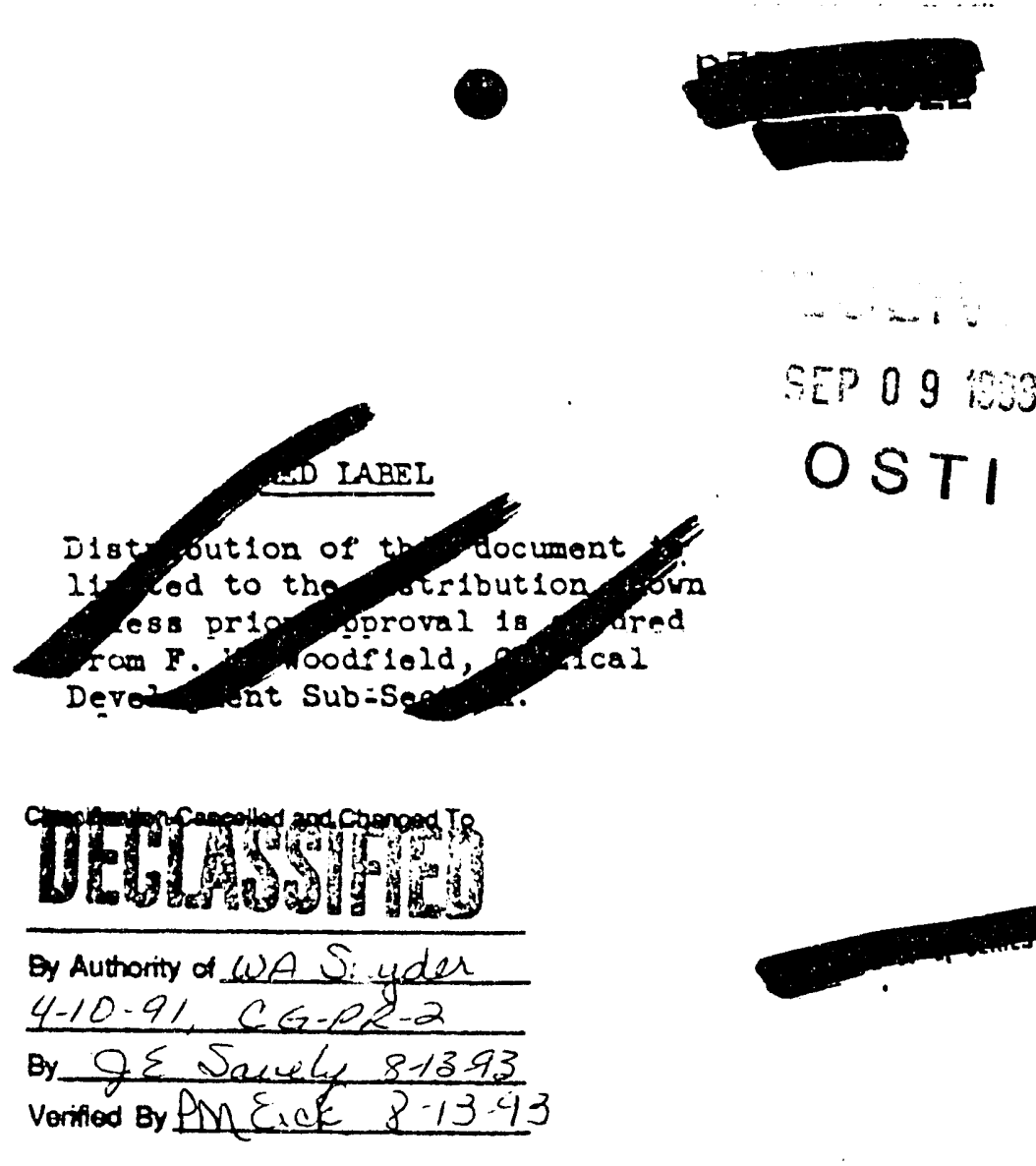

\section{OSTI Distrizut1on:}

1. O. F. B112

2. A. M. Piatt

3. ㄴ. R. Rea

4. R. B. Richards

5. R. E. Solth

6. R. E. Tomlinson

7. F. H. Hoodsleld

8-9. isxtra

10. 300 F1108

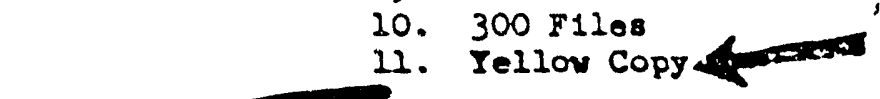

This document consists of

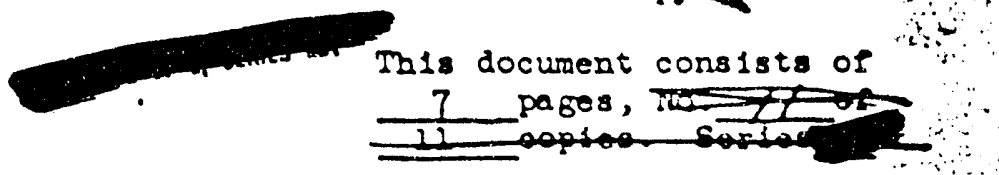

Apr11 12, 1955

TO: $\quad$ F110

FROM: A. M. Platt - Process studies $Q$ A $Q$

Procesa Plenning Unit

Chemlcal Devolopment Sub-Bection

200 AREA PROCESSINO RATE3

\section{INTRODUCTION}

Currently, two types of "foedytock"; 1.0., 1rradiated uranlum and uranlum frow unierground storage, are processed by the 200 Areas. Fut,uro operations my add 1rradiated thorium as a suoplementary foed materlal. In olther caso, the jar portion of future feedstocks 11 presumed to be in the form of 1rradiated matal; 1.o., uranlum and/or thorlum, esulting in an almost comploto dependenco or tho required 200 Ares processing rate on reector pover levels and metal irraciatic: istory.

\section{DISCLAIMER}

This report was prepared as an account of work sponsored by an agency of the United States Government. Neither the United States Government nor any agency thereof, nor any of their employees, makes any warranty, express or implied, or assumes any legal liability or responsibility for the accuracy, completeness, or usefulness of any information, apparatus, product, or process disclosed, or represents that its use would not infringe privately owned rights. Reference herein to any specific commercial product, process, or service by trade name, trademark, manufacturer, or otherwise does not necessarily constitute or imply its endorsement, recommendation, or favoring by the United States Government or any agency thereof. The views and opinions of authors expressed herein do not necessarily state or reflect those of the United States Government or any agency thereof.

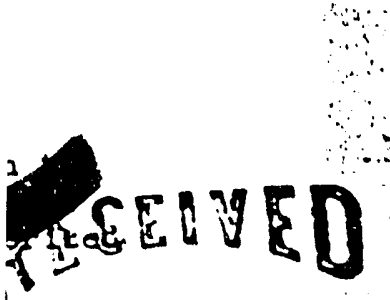

JUL 101956 300 AREA Ciñuitied FILES 
This document presents correlations by which predicted reactor power lovols and production combliments for particular types of product may be easily convorted to the required separations processing rates. Separations processlng rates potentially resulting rom low liGs plutonlum and "23" comitments are Elven for tho porlod through 1957 .

\section{SUSMARY}

The required motal processing rates in the 200 Areas (exclusive of the U.R. Fiant; are estabilshed by the rate of motal discharge from the reactors. These rates are, in turn, establ1shed by the reactor power lovel (Mr), integrated exposure of the metal (MWD/T), and loadings of polsons such as thorlun, lithium, etc.

The following tabulation 1temlzes tho requ1red uranium and thorfuir slug processing rates as a function of asaued product combltments and recent "bost" est1mates of anticlpated reactor pover levels. Pover in excess of that required to noet the low NGS and " $23^{n}$ comitments 1s ut1l1zed to produce $800 \mathrm{Mm} / \mathrm{T}$ plutonlum.

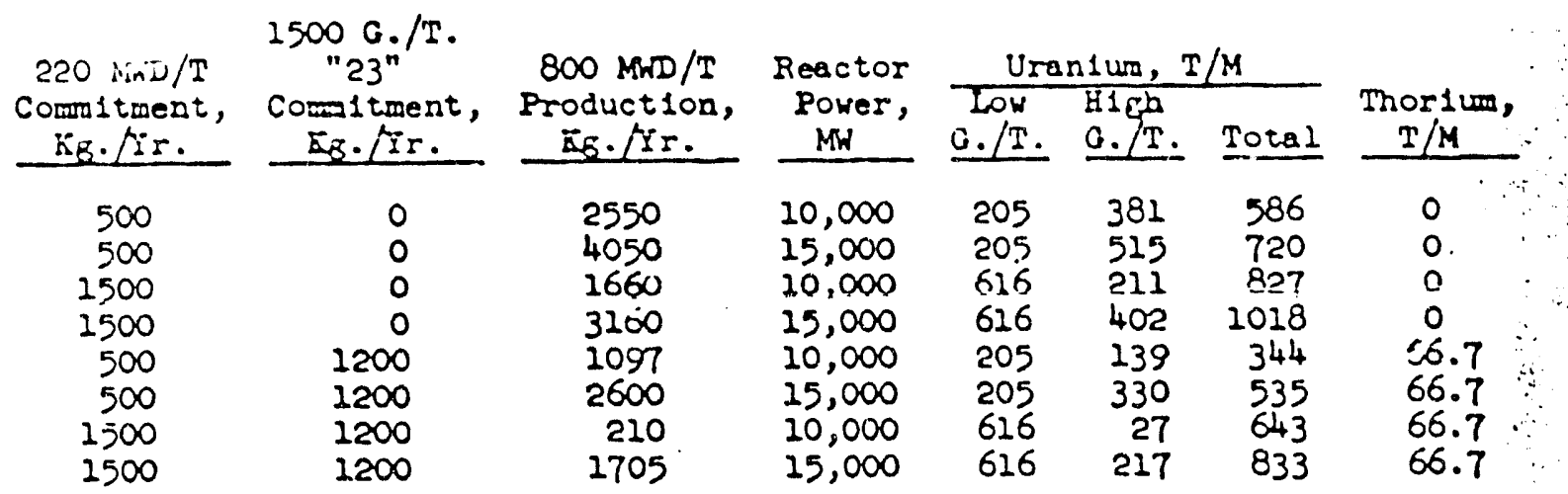

Processing rates resulting rrom other assumptions may be casily obtalned by use of the attached nomographs, F1gures 1 and 3 .

\section{DISCUSSION}

\section{Reactor Power Levels}

Realistic estimates of the maximum equilibrium porer levels that could be achleved by the sum total of the B.A.P.O. Feñiurs vary Irom about 10,000 MW in the summer of 1955 to $16,070 \mathrm{MW}$ in the yinter of 1056-1957. "Ilue sto" cst:=5tes of the maximum powor levels for the samo periods indicato $12,500 \mathrm{MW}$ and $17,000 \mathrm{MH}$, respoctively.

Estimates (see EH-33842) for the ind1v1dual Groups of 8 indlar reacturs aro as Lollows:

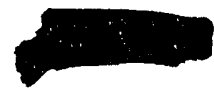


Megewatts

\begin{tabular}{|c|c|c|c|c|c|c|c|c|c|c|}
\hline \multirow[b]{2}{*}{ Dete } & \multicolumn{2}{|c|}{$B+D+D R$} & \multicolumn{2}{|c|}{$F+B$} & \multicolumn{2}{|c|}{$\mathrm{C}$} & \multicolumn{2}{|c|}{$K W+K E$} & \multicolumn{2}{|c|}{ Total } \\
\hline & Act. & $\operatorname{siax}$. & Act.* & $\operatorname{Max}$. & $\overline{\text { Act.* }}$ & $\operatorname{Max}$. & Act.* & $\overline{M a x}$. & Act..* & $\operatorname{Max}$ \\
\hline & 720 & 3490 & 30 & 238 & 350 & 194 & 240 & 652 & & \\
\hline & 2730 & 2990 & 1890 & 205 & 610 & $1 T 70$ & 480 & 560 & & 2 , \\
\hline & 2730 & 3490 & 1950 & 2380 & 850 & 1940 & 550 & 7680 & 13,080 & \\
\hline & 2910 & 2390 & 2030 & 205 & 0 & 173 & 6600 & 660 & & \\
\hline & 4600 & 4950 & 2410 & 2410 & 1850 & 1940 & 7000 & 7630 & 860 & \\
\hline & 4260 & 4260 & 2230 & 2280 & 1720 & 1720 & 6600 & 6600 & 14,860 & \\
\hline
\end{tabular}

* Realistic estimate.

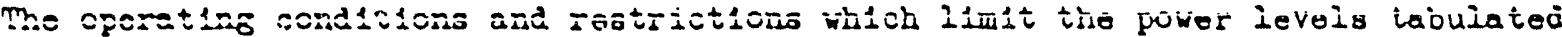
above may be found in the reference document (HW-33842).

It should be noted that the power levels given are instantaneuus values. Effective power levels may be calculated by multiplying the instantaneous power by an operating efflclency (such as $90 \%$ ).

Low NGS Plutonium

Low NGS plutonium compliments have been estimated at relues ranging from 0 to $1500 \mathrm{~kg} / \mathrm{yr}$. The Flle pover and uranlum processing retes assoclated with these comitments may be found by using the noxograph attached as Figure 1. Typlcal values from this figure are as follcws:

\begin{tabular}{|c|c|c|}
\hline $\begin{array}{l}220 \mathrm{MWD} / \mathrm{T} \\
\text { Plutonlum, } \\
\mathrm{Rg} \text {. Nr. }\end{array}$ & $\begin{array}{c}\text { Uranium, } \\
\mathrm{T} / \mathrm{M} \\
\end{array}$ & $\begin{array}{c}\text { Reactor } \\
\text { Power, } \\
\text { Mer }\end{array}$ \\
\hline $\begin{array}{r}0 \\
500 \\
1000 \\
1500\end{array}$ & $\begin{array}{r}0 \\
205 \\
412 \\
616\end{array}$ & $\begin{array}{r}0 \\
1485 \\
2970 \\
4450\end{array}$ \\
\hline
\end{tabular}

Uranium-233

"aう" $1200 \mathrm{Kg}$. of "23" per year. The reactor power consumption and thor lum processing rate necessary to meet these comitments have been calculated using F1gures 2 and 3. Flgure 3 is a nomograph quite similar to Figure 1.

F1gure 2 correlates "23" concentration in the thorlum 8 lugs with reactor prver consumption. As ind1cated in Figure 2, this relationship varies with tho typo or reactor loading and tho subsequent conversion ratso. An irradiation lovel of $1500 \mathrm{~g}$. "23"/ton thorlur and J-Q loading was assumed for the examplo given below.

\begin{tabular}{|c|c|c|c|c|}
\hline Looding & $0 . " 23 " / \mathrm{T}$. & $\begin{array}{l}n 23^{n}, \\
\mathrm{sg} \cdot \mathrm{Ir} .\end{array}$ & $\begin{array}{c}\text { Thor 1um, } \\
T / M\end{array}$ & $\begin{array}{c}\text { Reactor Pover, } \\
\text { MN }\end{array}$ \\
\hline$J-Q$ & 1500 & 1200 & 66.7 & 4850 \\
\hline
\end{tabular}

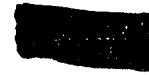


It is ant1cipeted that all excess reactor power avallable (after meeting low NGS plutonium and "23" commitments) w11l be ut1lized in the production of h1gh NGS plutonlum. The irradiation level of this materlal will probably fall in the rango of 600 to $1000 \mathrm{MWD} / \mathrm{T}$. Tabular data 1nd1cating reactor power, plutonium product1on, and uranium processing rates for $800 \mathrm{MWD} / \mathrm{T}$ materlal are given below fur total effective reactor power levels of 10,000 and $15,000 \mathrm{MW}$.

\begin{tabular}{|c|c|c|c|c|}
\hline 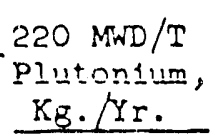 & $\begin{array}{l}\text { "23", } \\
\mathrm{Kg} \cdot \mathrm{Yr} .\end{array}$ & $\begin{array}{c}\text { Reactor Power } \\
\text { to EIgh NCS, } \\
\text { MW } \\
\end{array}$ & $\begin{array}{c}\text { Uren1um, } \\
\mathrm{T} / \mathrm{M} \\
\end{array}$ & 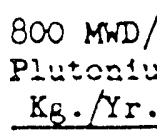 \\
\hline $\begin{array}{r}0 \\
500 \\
2000 \\
1500\end{array}$ & $\begin{array}{l}0 \\
0 \\
0 \\
0\end{array}$ & $\begin{array}{r}10,000 \\
8,515 \\
7,030 \\
5,550\end{array}$ & $\begin{array}{l}381 \\
324 \\
268 \\
211\end{array}$ & $\begin{array}{l}2970 \\
2550 \\
2100 \\
1660\end{array}$ \\
\hline $\begin{array}{r}0 \\
500 \\
1000 \\
1500\end{array}$ & $\begin{array}{l}1200 \\
1200 \\
1200 \\
1200\end{array}$ & $\begin{array}{r}5,150 \\
3,665 \\
2,180 \\
700\end{array}$ & $\begin{array}{r}196 \\
139 \\
83 \\
27\end{array}$ & $\begin{array}{r}1542 \\
1097 \\
651 \\
210\end{array}$ \\
\hline & & Eotal Power - 1 & $\mathrm{MW}$ & \\
\hline $\begin{array}{r}0 \\
500 \\
1000 \\
1500\end{array}$ & $\begin{array}{l}0 \\
0 \\
0 \\
0\end{array}$ & $\begin{array}{l}15,000 \\
13,515 \\
12,030 \\
10,550\end{array}$ & $\begin{array}{l}571 \\
515 \\
450 \\
402\end{array}$ & $\begin{array}{l}4490 \\
4050 \\
3000 \\
3160\end{array}$ \\
\hline $\begin{array}{r}0 \\
500 \\
1000 \\
1500\end{array}$ & $\begin{array}{l}1200 \\
1200 \\
1200 \\
1200\end{array}$ & $\begin{array}{r}10,150 \\
8,666 \\
7,180 \\
5,700\end{array}$ & $\begin{array}{l}386 \\
330 \\
273 \\
217\end{array}$ & $\begin{array}{l}3040 \\
2600 \\
2150 \\
1.705\end{array}$ \\
\hline
\end{tabular}

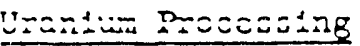

The total quantity of 1rradiated uranium which must be processed is the sum of thrt ut1lized for both low NGS and hich NGS plutonium procensine. The maximum uranium processing rate will occur when (a) a high reactor powe: level is developed $(15,000 \mathrm{MW})$, (b) a high commitment of low NGS plutonium is invelved (2500 $\mathrm{Kg} \cdot / \mathrm{yr}$. ), and (c) no "23" production 1s required. A uranium processing rate of iols tons $U$ per month must be achleved in this case (in addition to the processing of any uranium from underground storage). A minlwue processing rate is achleved when the reactor power level is low $(10,000 \mathrm{MW})$, no low NGS plutonium commitment is 1nvolved, and a hleh ( $1200 \mathrm{Kg}$.$) "23" commltrant must be met. In this case, the urenius processing$ rate drops to 196 tons per month.

Other cases, us well as the minimun and maximuiii situation desclelued above, ure: clted in the summary of this report.

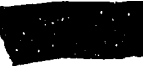




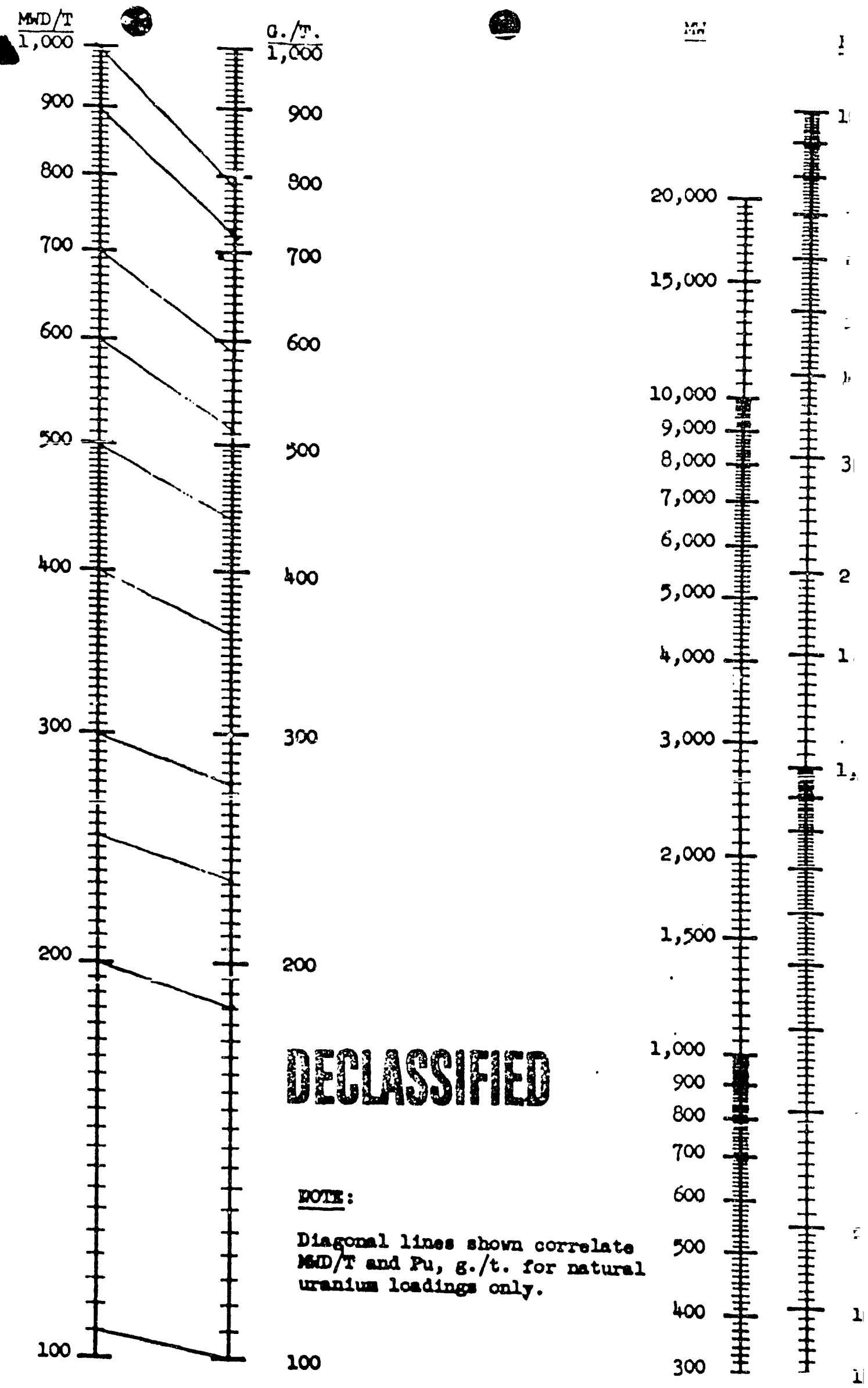




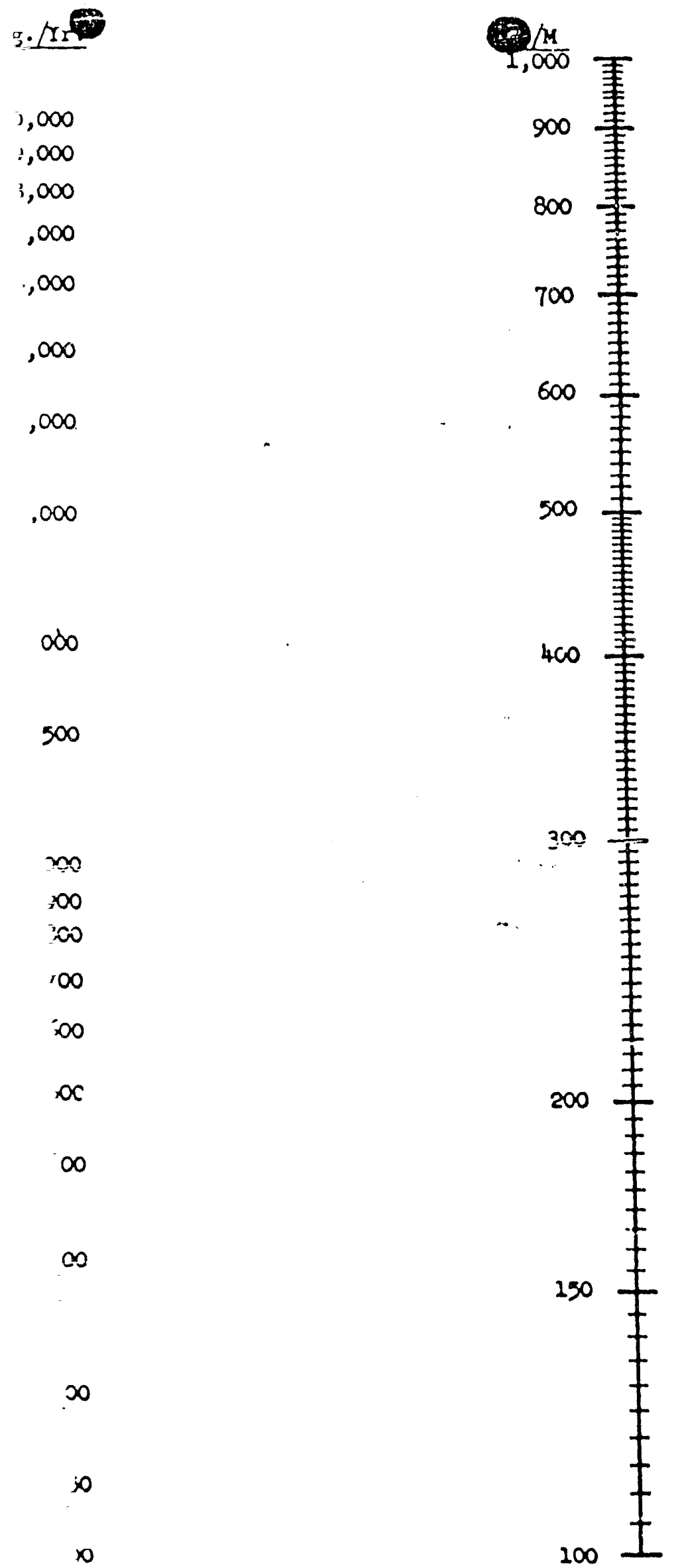

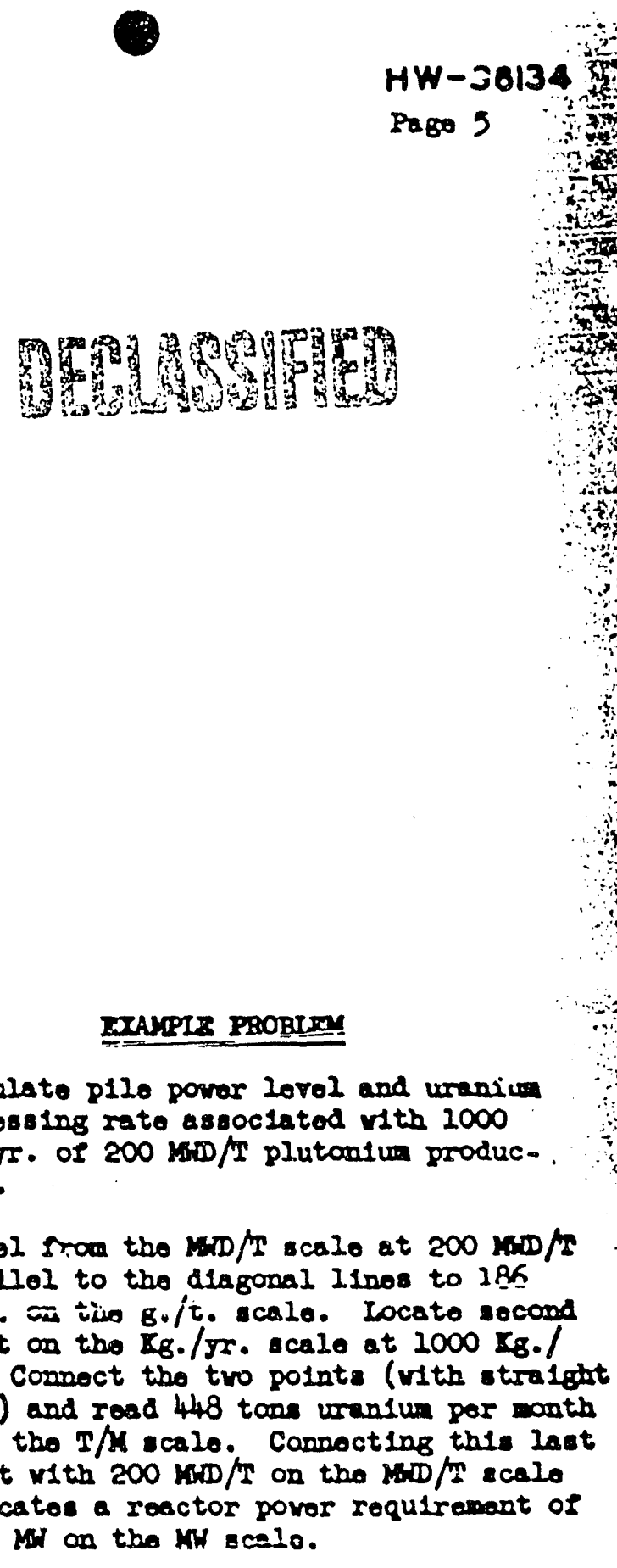

Calculate p1lo porvor lovel and uraniu procossing rato assoclatod with 1000 Kg./yr. of 200 KiDD/T plutontum product1on.

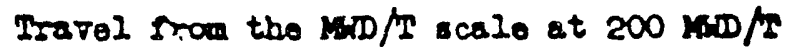
perallel to the dingonal linos to 186

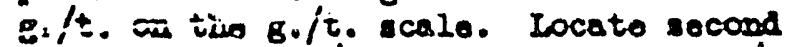
polnt on tho K8./gr. scale at $1000 \mathrm{~K} 8 . /$ J.. Connoct tho two points (with strolght odso) and rood 448 tons uransun par month sron tho T/M scale. Connocting thl last polnt with $200 \mathrm{MND} / \mathrm{T}$ on tho $\mathrm{ND} / \mathrm{s}$ ecalo indicatos a reactor povor requiremant of 2950 on the WH scelo.

\section{IIGORES I}

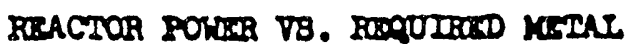
PROCRSBIIO RATE 


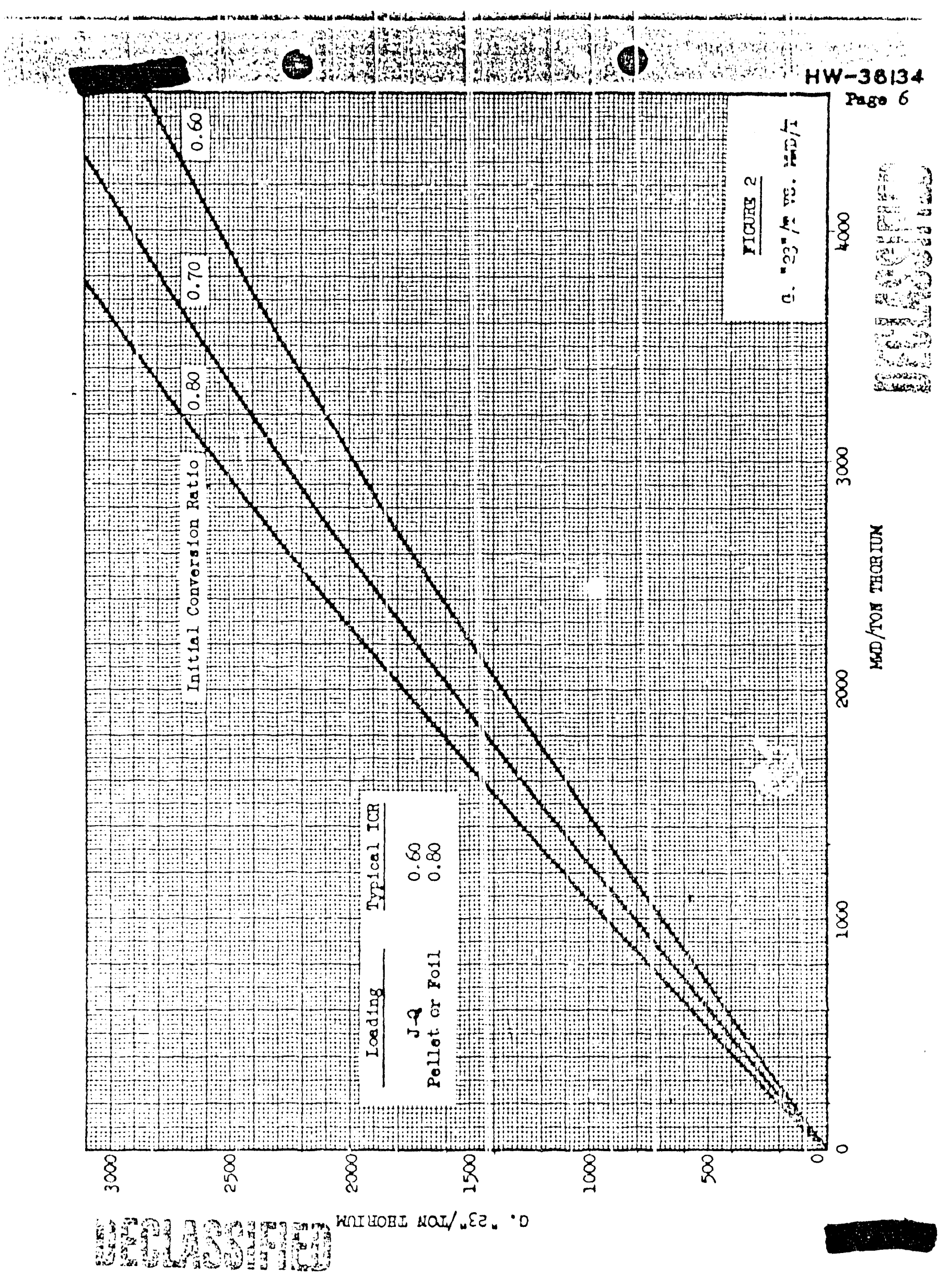



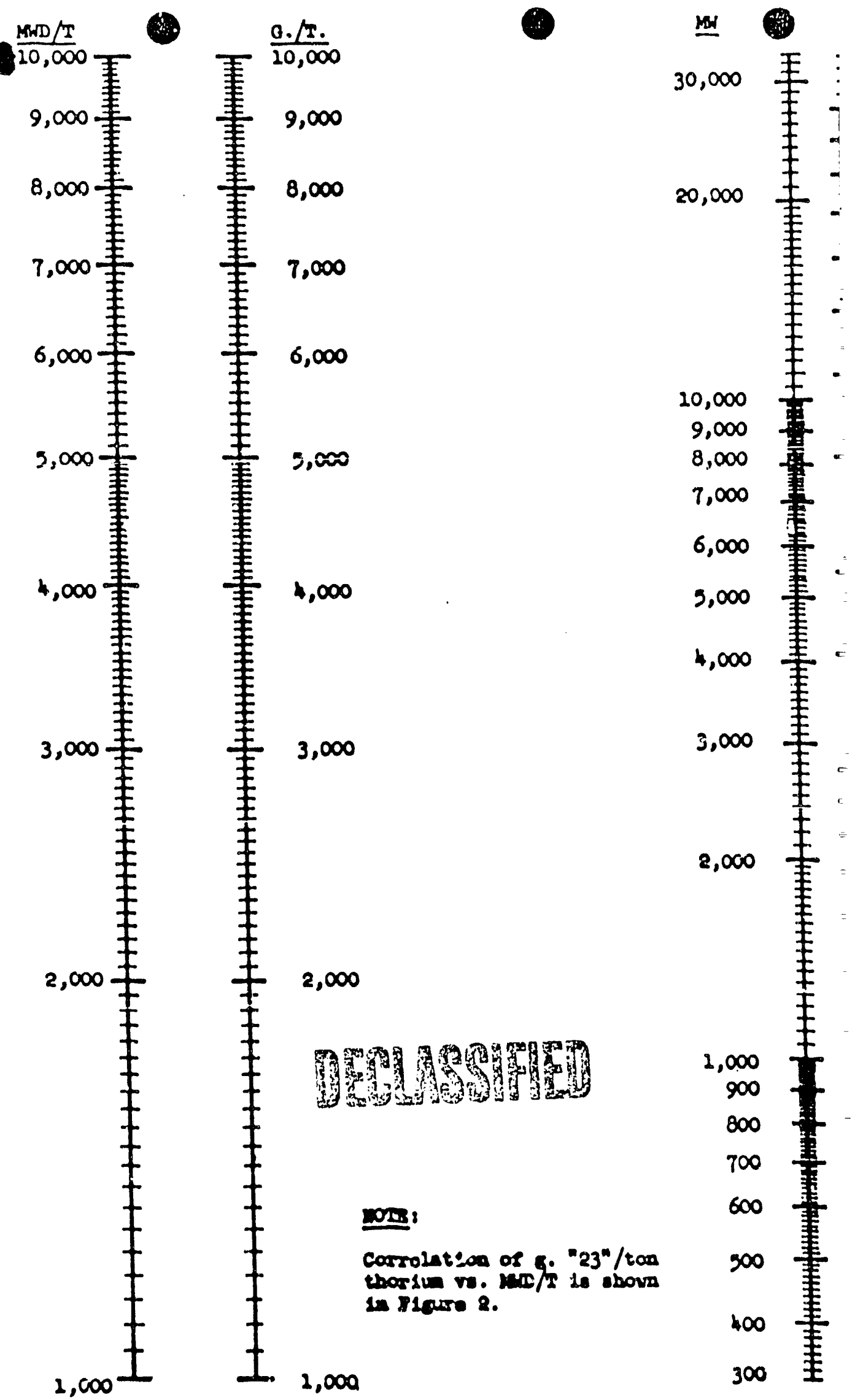


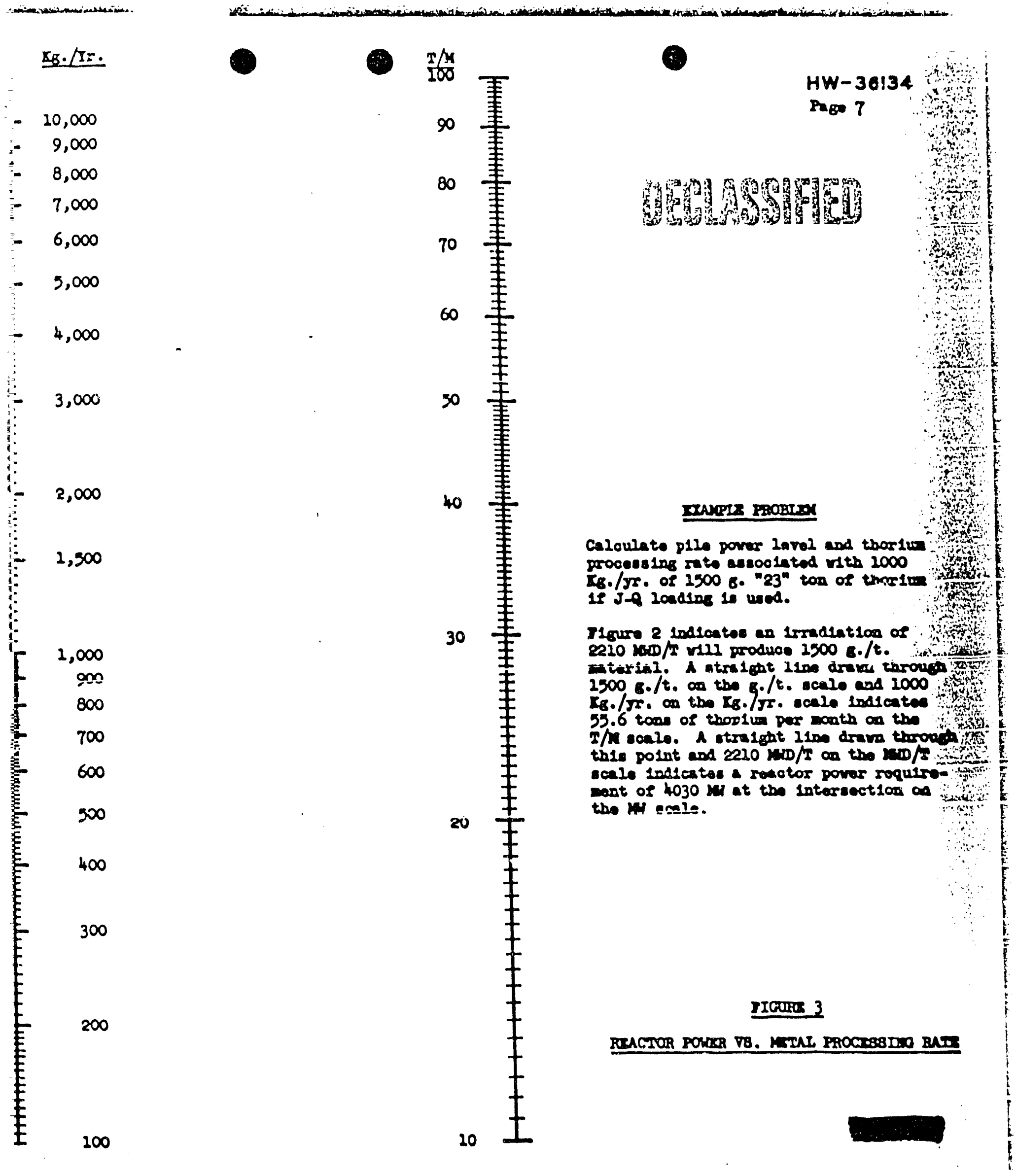



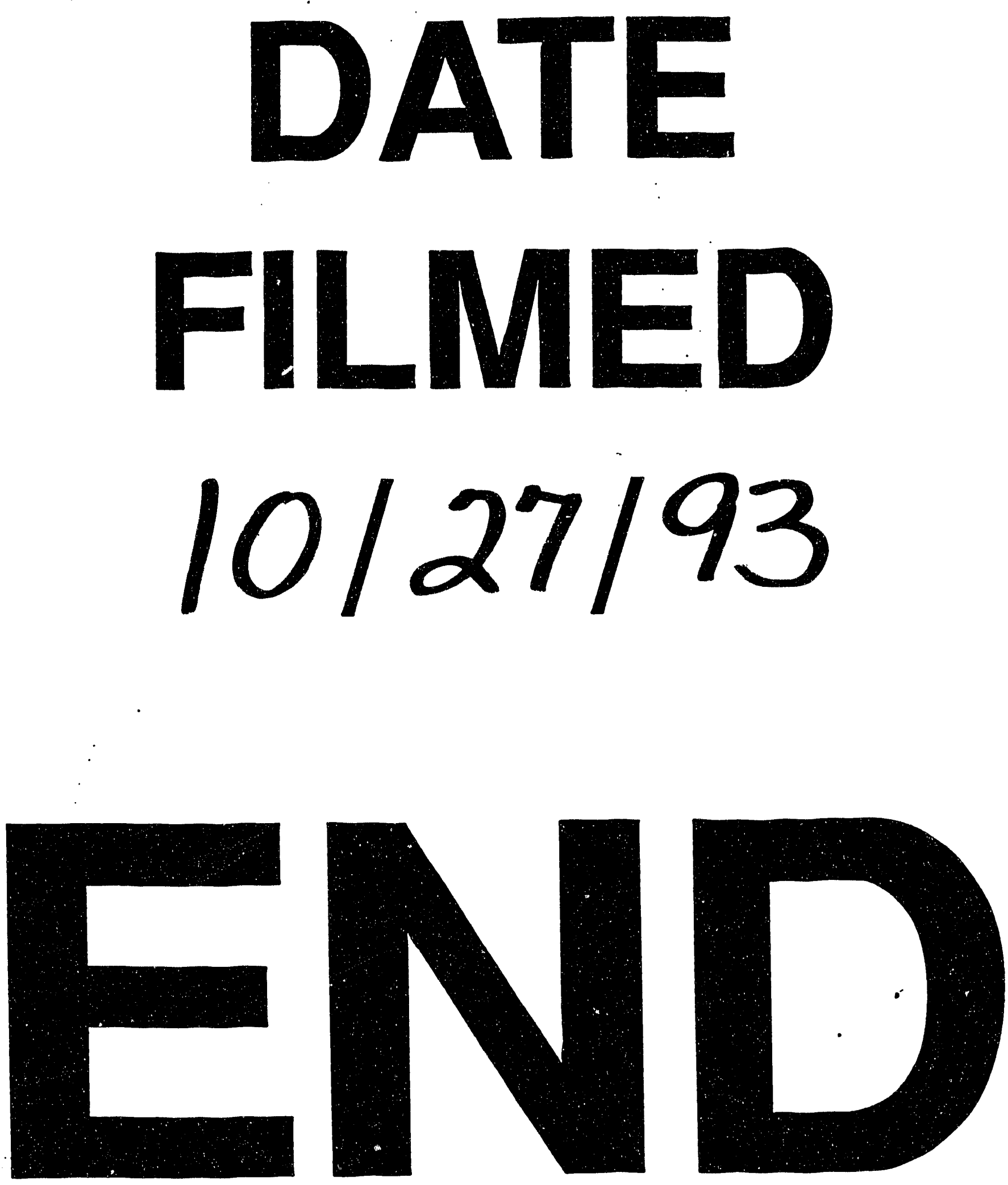